\title{
CLIL-Oriented and Task-based EFL Materials Development
}

\author{
Suhandoko \\ suhandoko@uinsby.ac.id
}

UIN Sunan Ampel Surabaya, Indonesia

\begin{abstract}
This Research \& Development (R\&D) aims at developing materials in the form of a coursebook prototype for the tenth-grade students of senior high schools in Indonesia. Teacher interviews and students questionnaire were used to assess the users' needs. The data revealed that the existing materials are not relevant to the students' needs majored in studying Math and Science (Biology, Chemistry, Physics). So there is a need for developing new materials by orienting to quality CLIL materials principles and task-based approach. In general, based on the validation checklists, the materials were considered reliable by the English teachers, the EFL material and language expert and the media expert. The final product was also considered acceptable by the students and teachers based on the questionnaires distributed after the limited-field tryout. The study resulted in three main products: Student Book, Teacher's Guide, and Listening Audio CD.
\end{abstract}

Keywords: Materials development, CLIL, Task-based approach

\section{INTRODUCTION}

Globalization and the advancement of technology have brought huge impacts toward education, unexceptionally foreign language teaching, or in this case particularly English language teaching (ELT). Correspondingly, there is a shift value about the language teaching perspective especially on how and what to teach to answer the global changes. Changes in viewing foreign language education have also brought many implications that should be responded well by all supporting factors of successful education, one of which is the availability of textbooks that are relevant to the users' needs and global changes and challenges (Tomlinson, 2011).

When faced with the implementation of CLIL in EFL classrooms, the existing materials are likely believed not to be able to meet the needs of responsiveness to the context in which CLIL is applied. This is reasonable because most books publishers create their books for the benefits of wide use and for business and money orientation (Gray, 2010; Sherman, 2010; Banegas, 2013). Even if it is recognized that the materials are already considered as sufficient to encourage the learners' ability to communicate in the target language, quality materials are materials that in addition to encouraging the 
communicative abilities, it may also promote the learners' ability to encourage their critical thinking skills, help them to realize the shortcomings and the limitations of their knowledge, and most importantly to encourage them to keep exploring additional information required in order for self-development and for contribution to mutual problem solving.

Banegas (2014) reports that the books under his investigation which were claimed by the publishers as to contain language-driven CLIL-related sections within the books show very little indication of CLIL. He found that the considered-CLIL sections in the books are merely oversimplification of the contents and teaching the materials students already familiar with and the superficial activities which do not bring to mind any schoolsubjects curriculum or the potential users' (students) cognitive development. It appears that instead of being valued to constitute thoughtful and inventive integration of content and language, those books can be considered as a "half-hearted" investment that cannot appreciate its intended benefits by integrating contents and language. This finding is similar to what the researchers found that English books published by local publishers in Indonesia do not include topics related to other subjects that are of interest to students, even if there are very few.

Being aware of these conditions, the researcher assumes that English materials that incorporate subject topics that are also of interest to students are still very much needed. This study aims to develop teaching materials in the form of textbooks that attempts to incorporate subject topics that are also of student interest, in this case mathematics and science.

\section{REVIEW OF RELATED LITERATURE}

\section{CLIL and Task-based Approach}

As a pedagogical approach especially in ELT, task-based learning has evolved into a variety of models to be adjusted to the ELT contextual needs and aims. Ellis (2009) states there are no single correct models referring to the proper task-based language teaching and learning. A task requires outcome which means doing a task in foreign language teaching, the outcome is communicative outcome (Ellis, 2003:8). As an approach to foreign language learning, CLIL is actually not far detached from communicative approaches in ELT that it promotes naturalistic acquisition and meaningful use of L2, and therefore its application is not contradicted with task-based learning since meaning is primacy.

The relevance of task-based learning with CLIL is found in the possible tendency for CLIL teachers to make learners work on the abundant input or texts and alleviate the possibility of the promotions of participation in thinking about, talking about, and discussing the content. This provides a means of adjusting the input to the learners by breaking down the input through sequential tasks. Ellis (2009:224) suggested that a task may become an "input-providing" or "output-prompting" which also means CLIL tasks should be designed to encourage the opportunities for both input and output.

The tendency of the immense use of literacy texts as the source of input in CLIL instruction strengthens urgent needs for tasks employment in which students are engaged in several meaningful language tasks to accomplish by making linguistic input comprehensible, being stimulated to produce the target language, interacting with other 
people, collaborating with peers, and engaging in negotiation of meaning during which teacher may examine language outcomes and, further, provide both linguistic and content evaluation (Nunan, 2004 p.4; Van den Branden, 2006, Willis, 2006; Harmer, 2007:71; Brown, 2007:50). To this point, CLIL and task-based approach are, therefore, "bidirectional" (Moore and Lorenzo, 2015) in the sense that CLIL provides rich input for the teaching and learning of ELT while task-based enables the input to be comprehensible.

\section{CLIL-Oriented and Task-based EFL Materials}

Coyle et al. (2010) suggested 4Cs framework in developing a quality CLIL materials which comprise Content (subject matter), Cognition (learning and thinking process), Communication (language learning and using), and Culture (developing intercultural understanding and global citizenship). While Banegas (2013) and Garcia (2013) suggested three frameworks of Mohan's Structure Knowledge, Bloom's Cognitive Taxonomy of Anderson and Krathwohl's version, and Cummins' Matrix. Actually these four frameworks are interrelated to each other.

The 4Cs framework stands for Content (subject matter), Cognition (learning and thinking process), Communication (language learning and using), and Culture (developing intercultural understanding and global citizenship) (Mehisto et al. 2008:31; Coyle et al. 2010:104). Coyle et al.'s Content aspect actually shares similar characteristics with Mohan Structure of Knowledge. According to Mohan (1983:35) in order that the materials are palatable to the students, it should provide schema building activities that students' prior knowledge should be used in the initial learning tasks. In Coyle et al.'s 4Cs framework, the aspect of Content in EFL context might be meant as the cross-curricular or thematic for example global warming issues, social issues, climate change issues and so on which can be contextualized in both content and language contents.

As for Coyle et al.'s Cognition aspect of 4Cs, it shares things in common with Anderson, Krathwohl \& Bloom's (2001) cognitive taxonomy in which human can accomplish a task if is arranged from the simplest (lower-order thinking skills) to the most difficult tasks (higher-order thinking skills). In Cognition aspect, the thinking skills required in content learning are analyzed. The materials should allow students to construct their own understanding and at the same time be challenged cognitively (Coyle et al. 2010:54) through reflection and engagement in lower-order thinking skills (LOTS) and higher-order thinking skills (HOTS).

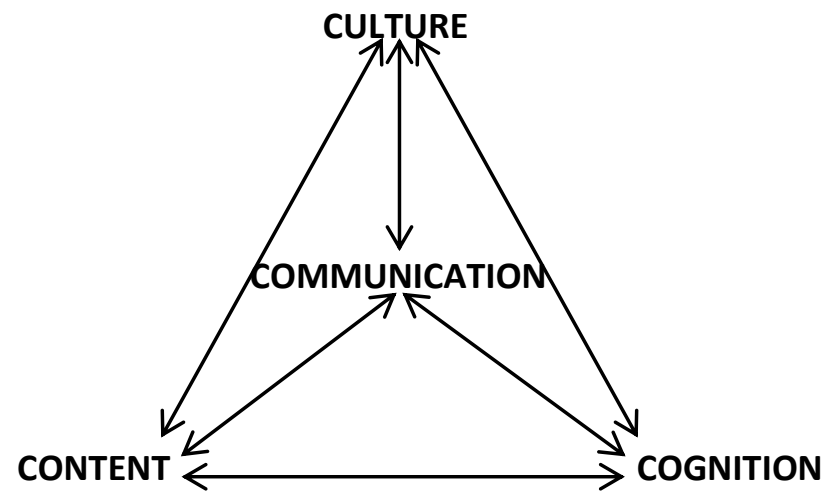

Figure 1. 4Cs Framework of CLIL (Coyle et al. 2010) 
The communication aspect of Coyle et al.'s 4Cs also shares similar characteristics with Cummins Matrix. According to Cummins (1984, 1999, 2000), tasks should not only be linguistically accessible but also cognitively demanding. Cummins describes that tasks can be arranged into four matrixes from a low linguistic-cognitive undemanding tasks to high linguistic-cognitive demanding tasks. Matrix ' $a$ ' is aimed at encouraging student's confidence through familiar works or knowledge as a point of reference; Matrix ' $b$ ' is aimed at recycling language required in communicating content; Matrix 'c' is aimed at developing students' new knowledge and at the same time the language is extended into more complex structures required to carry activity; and Matrix ' $d$ ' is the final tasks where students are already capable of producing new language when at the same time creating new knowledge. Matrix ' $a$ ' and ' $b$ ' are referred as Basic Interpersonal Communication Skills (BICS) while 'c' and 'd' are referred as Cognitive Academic Language Proficiency (CALP).

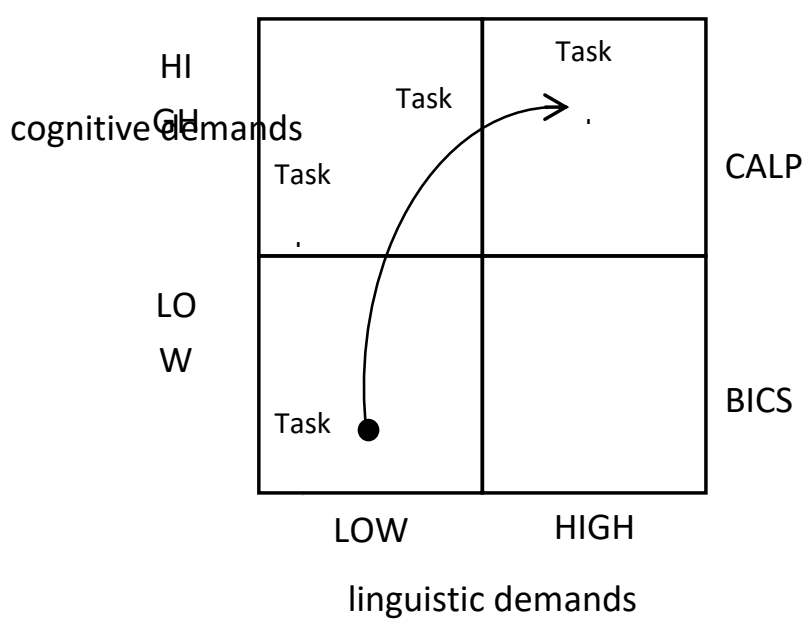

Figure 2 Tasks in CLIL Matrix (Coyle et al. 2010:68)

The abovementioned 4Cs actually ends in the Communication aspect. The Content, Culture, and Cognition aspect of 4Cs framework actually is the process supporting the students to communicate their knowledge accurately in terms of content and meaningfully in terms of the context (the culture of certain specific academic). In the effort to make interrelationship between content and language objective, Coyle et al. (2010: 36-38) develop Language Triptych to organize the tasks better consisting three aspects: Language of learning, Language for learning, and Language through learning. In Language of learning, students are exposed to the tasks that enable them to explore the language e.g. the keywords or the phrases they need to access content. The second aspect is Language for learning which focuses on the language students require to carry out classroom tasks such as explaining, describing, evaluating, discussing, debating, etc. The third aspect and is the ultimate goal of the Language Triptych is the Language through learning. It is expected that after a series of language exposure, students also develop their skills in language as Garcia (2013) states that students "make room for unpredictable language learning that may arise as the lesson unfolds".

The four frameworks underlie the product design in the present study become the guidance to select the contents, grade the materials and sequence the tasks. In order to promote students' both linguistics and cognitive skills, the content selection would heed on 
several features, for example, the use various genre and text types, the use of multimodality inputs to foster comprehension and employment of cross-curricular content (Tomlinson, 2011). Materials grading refers to how the contents are organized while sequencing refers to how language items are ordered (Cunningsworth, 1995:59). Materials grading and task sequencing are aimed at promoting students' cognitive development from the lower order (i.e. remembering) to a higher order (i.e. evaluating). Not only materials grading and tasks sequencing resulted from the thinking skills analysis in the cognition aspect, but also how to scaffold input and output, how tasks were interdepended, how language was recycled to foster long-term retention, how learning can be experienced rather than just a passive activity, how languages were produced creatively, and how learning could be reflected for the betterment of language acquisition (Nunan, 2004: 3538).

As a guide in planning materials grading and task sequencing, a revision of Bloom's taxonomy (Anderson, Krathhowl \& Bloom, 2001) was employed to enable learners to undergo thinking skills from the lower to the higher-order thinking skills, from remembering to creating. Although the order reflects knowledge processing and knowledge acquisition, it is not recommended to follow the order rigidly; instead, the taxonomy is used as source for planning the material sequence.

Grading and sequencing are closely related to how tasks are developed in a coursebook. In the present study, the tasks were developed following Ellis' (2009) model of task-based learning: pre-tasks, tasks, and post tasks. Specifically for productive language, controlled, guided and free practices are involved. Controlled practices refer to the practice where students' choice of language is restricted with a single answer for example gap-filling. Guided practices refer to the stage which allows students to use some creative language of their own. Free practices refer to the activities which involve more language choice by the students. The practice should be focused more on the meaning rather than the form or focused on content rather than the language itself. In this case fluency is more encouraged than accuracy.

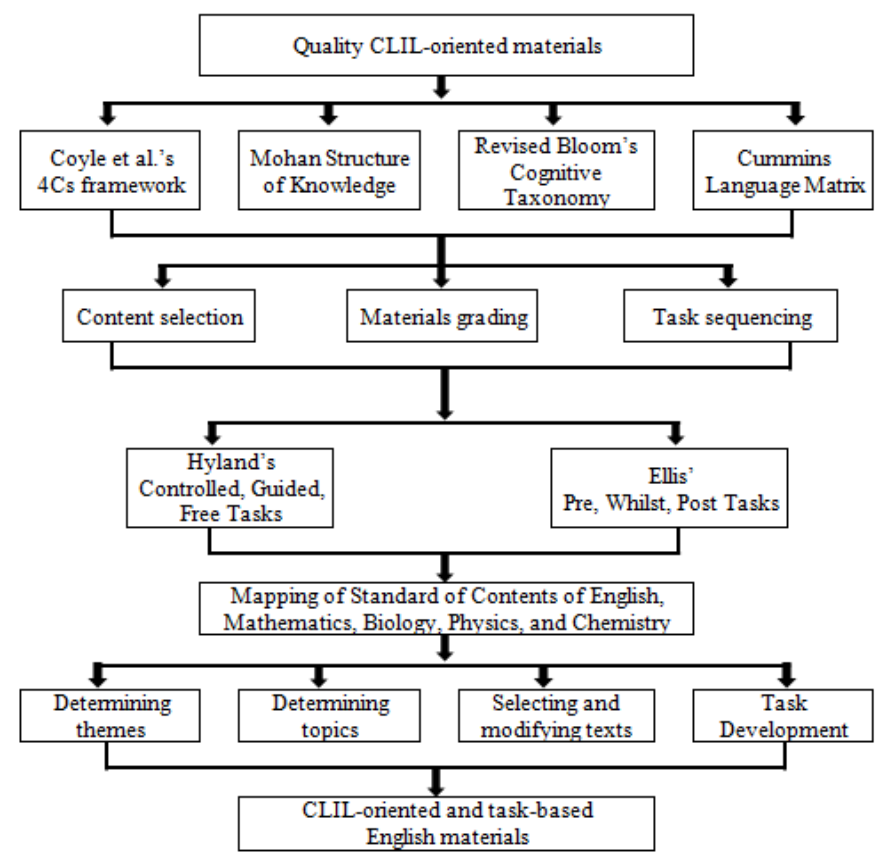


Figure 3. Conceptual framework of CLIL-oriented and task-based EFL materials

After the conceptual framework has been established, a careful look into the present curriculum is conducted. Specifically, the development of the product in the present study involves five subjects: English, Biology, Physics, Chemistry, and Mathematics. For the purpose of inputs, Standards of Content of each subject were mapped to know whether the contents were executable in the teaching and learning of foreign language. Because Curriculum 2006 of English employs genre-based approach (GBA), the easiest way to incorporate all those contents is by setting themes that can cover all contents. Theme-based development is helpful especially to accommodate a development of a concept which later can be a foundation in understanding, thinking, and arguing (Kostelnik, 1991). Once themes are determined, can only be then the topics developed.

\section{METHOD}

\section{Participants}

167 of senior high school students in Jombang, East Java, Indonesia participated in filling the questionnaire for needs assessment purposes. In addition, three English teachers were involved in a semi-structured interview to investigate the present situation related the existing materials used in English class. Six content teachers (Biology, Physics, and Chemistry) were also involved in Focus Group Discussion (FGD) to discuss the readability of the texts used in the materials developed in the present study. After FGD, two English teachers, an EFL material and language expert, and a media expert were involved to evaluate the materials developed. 34 students and an English teacher finally participated in a limited-field tryout of the materials and in filling out the questionnaire to measure the practicality and acceptability of the materials.

\section{Procedures}

Product development in the present study employed a research and development (R\&D) model adapted from Gall, Gall \& Borg's (2003) model, Schlegel's ADIIE (1995) model, and Lee and Owens' (2004) model which are summarized into six main stages: (1) needs assessment, (2) designing the product, (3) developing the product, (4) validation and revision 1, (5) limited-field tryout and revision 2, and (5) final product.

In the needs assessment stage, a semi-structured interview was conducted to gather information from two English teachers related to their experiences of using and expectations of the materials in their English class. A questionnaire was also distributed to 167 students related to their learning experiences in their content and English classes as well as their perceptions whether a new material was required. 
In the stage of product design, the researcher set the conceptual framework of how the product would be developed. In the present study the researcher deployed (i) Coyle et al.'s (2010) 4 Cs frameworks consisting of cognition, content, communication, and culture, (ii) Anderson's version of Bloom's Cognitive Taxonomy, (iii) Mohan's Structure of Knowledge, (iv) Cummins' CLIL Matrix, and (v) task-based approach. The conceptual framework based on the theories presented in the preceding subheading 2.2 is presented in Figure 1. In addition to it, the structure and the physical form of the product were also planned and designed. In the design stage, the kind of text was determined in which recount text was selected because it was the first genre taught in the tenth grade in the first semester. After the text type was selected, tasks were designed. The tasks covered all language skills and components with some additional tasks, for example the schemata building tasks, extensive reading tasks, cultural awarenessraising tasks, and ESL Tips. In the development stage, themes and topics following the Math and Science contents were developed. After the topics were developed, texts were then carefully selected from various sources before it was modified. The modification was done by heeding on the guideline set by Coyle et al.(2010) in modifying CLIL-related texts; (1) the focus of the message whether the content is as targeted, (2) the clarity of the message that it should be expressed in an accessible way, (3) the mix of textual style of presentations e.g. visuals, tables, diagrams, charts, graphics, bulleted information and so on (4) the right level of subject-specific vocabularies, (5) the appropriate level of general vocabulary, (6) the appropriate level of grammatical complexity, (7) the clarity of the thread of thinking, (8) the appropriate cultures of the target users. After the texts were modified, a Focus Group Discussion (FGD) involving content teachers were conducted. Once the texts were assessed qualitatively and revised based on the content teachers' suggestions, they were then assessed quantitatively using Flesch-Kincaid readability tests. The criteria of the texts which would be used in the prototype of product were 60 to 70 because such texts were supposed to be easily understood by students aged 13-15 (Bravos, 2010). Only after the texts were considered appropriate to be used, tasks were then developed and the Listening CD and Teacher's Guide would be established.

In the validation phase, two English teachers, an EFL materials and language expert, and a media expert were involved in judging the first draft of the product. Using validation checklists, validators were asked to give comments and feedback for the purpose of product revision.

After the products were validated by experts and the revisions were done following the qualitative feedback given by the experts, the products were then used in a limited-field tryout. In the tryout, in addition to observation using fieldnotes, the researcher set up teacher and students' questionnaire to give their comments on the product whether the products were acceptable. Finally, after the products were validated in the tryout stage, the products were then revised and arranged into the final product. 
However, due to financial and time constraints in which the researcher was bound by in his study, he decided to develop a prototype of materials. Based on the selected text namely recount text, two units were developed considering the following situation. In senior high school in Indonesia, the tenth graders are required to study three texts in the first semester: recount, narrative, and procedure. In one semester, there are about eighteen weeks available for teaching and learning; therefore, each text is likely provided with six weeks of two meetings each to accomplish. Hence, a text can be finished in 12 to 14 meetings depending on the complexity of the text types. It is unlikely possible to develop a unit with one theme for 12 to 14 meetings because it will likely lead to students' boredom. Considering this, two units with different themes were developed to make the materials varied and elude the possibility of boring materials. The units are Unit and 2 which were developed following the current syllabus of English and maths and science lessons in Curriculum 2006.

\section{FINDINGS AND DISCUSSION}

\section{Results of the Development}

In the development stage, two themes (biography and past experience) with nine topics (classifications of living things, characteristics of living things, virus, periodical system, the Law of Conservation of Mass, ionic and covalent bonding, atomic structure, measurement, and algebraic manipulation) were developed.

Once the themes and topics were developed, texts were selected from various resources, mainly from the internet. The text modification was done following Coyle et al.'s guideline as previously presented. After the texts were modified, FGD was conducted by involving content teachers. Six teachers were involved in the FGD to verify the content and readability of the texts. After the texts were assessed and revised, they were measured using Flesh-Kincaid readability tests to know the readability of the texts. From the calculation, it was found that all texts were between 60 and 70 according to Flesch-Kincaid reading grade which means the texts were suitable for the tenth-grade students 13-15 years old of age.

After the texts were verified, tasks were then developed or in this case created. All tasks covered all language skills (listening, speaking, reading and writing) and components (vocabulary, grammar, and punctuation) with additional tasks covering the schemata building tasks, extensive reading tasks, cultural awareness-raising tasks, and ESL Tips. After the tasks were developed, the pages were compiled and the Teacher's Guide and listening audio CD were established for validation preparation. 


\section{Results of Validation}

Based on the validators' evaluation, the researcher got some positive comments and suggestions for revisions related to the product prototype developed in this study. First, in terms of content, the validators judged that the product prototype has matched to the present curriculum and syllabus being used, the activities can be exploited as a whole using various ELT methodologies, the suitability of the materials with the learners' age, needs, and interests, and the consideration to address cultural sensitivities.

The second aspect judged by the validators was the linguistic aspect of the product prototype. In general, the experts perceived positively about the aspect of language in the product, however, they commented that there were few grammar errors found throughout the book which should be taken into account for revision. In addition, one of the validators commented on the use of Calibri font type as he perceived that it might lead to confusion in distinguishing between characters.

The third aspect evaluated was the presentation of the materials prototype. All experts gave positive comments especially because the product prototype was developed covering all language skills and components. However, the expert validator commented that the researcher should consider rearranging the tasks especially the listening and speaking tasks. She commented that all listening tasks should be put together in one section and so should the speaking tasks in order that the users were not confused with the logic of the tasks sequence.

The last aspect evaluated is the graphics of the product prototype. The expert commented that the graphics used were interesting. However, the evaluation of graphics aspects by the English teachers and expert were considered inadequate; therefore, a media expert was involved to validate the graphics of the product.

The first aspect evaluated by the media expert was the format of the product prototype. The media expert gave positive feedback for the format of the book that is has satisfied the ISO standard and appropriate between the size and contents of the product prototype. The second aspect evaluated was the cover design. The media expert commented on the use of different font type of the cover. He recommended using the same and not bolded font type for the covering to make the cover more appealing and not too crowded. In addition, he suggested enlarging the book title in the cover. The third aspect evaluated was content design. The media expert suggested using 6 pt. after spacing throughout the book to make the text more readable and using the same font type throughout the book to avoid confusion. The other aspects were paper quality, printing quality, and binding quality which was positively judged by the media expert. In his final remark, the media expert suggested the researcher using another san-serif font type instead of Calibri because Calibri might lead to confusion among characters. $\mathrm{He}$ suggested using Andika as alternative to Calibri. 
After the product was validated, it was then revised based on the qualitative feedback given by the validators. The revisions were generally in the aspect of grammatical inaccuracies throughout the product and also the sequence of listening and speaking activities which required to be reordered.

\section{Results of the Limited-Field Try-out}

An English teacher and 34 students were involved during the limited-field tryout of the product in the present study. Equipped with a field-notes sheet, the researcher observed the application of the product in the classroom. During his observation, he found a number of important things which showed that the materials were acceptable for the learners noted as follows: (1) students were engaged in joining the lesson by giving comments and responding to the teacher's questions related to a topic although they responded in their L1, (2) students were very enthusiastic especially in doing the project in Unit 2 because they conducted a laboratory experiment, (3) students were also curious with the information related with ionic and covalent bonding. They said that they wanted to have the experiment as illustrated in the text, (4) in the process of teaching and learning, the teacher implemented the steps as suggested in the Teacher's Guide efficiently, (5) apart from the activities as suggested in Teacher's Guide, the teacher, with the researcher's consent, also decided to add some extra activities by playing games and using various teaching strategies, and (6) teacher did not do the differentiated activities as suggested by the Teacher's Guide to help less-proficient learners.

Overall, the teacher judged positively about the product indicated by his perceptions about the contents of the Student Book which covered all the topics appropriate with both language and content materials. Likewise, the teacher judged the Student's Book has been well-developed considering all language skills integration and balance. In addition, the activities in the Student Book, as represented in the scores given in the questionnaire, are believed to flourish students' knowledge and skills in the materials discussed, engage students actively in the teaching and learning process, enable students to use the book either under teacher supervision or as self-study, make best use of their prior knowledge of content subjects in English learning and challenge students' critical thinking skills. The teacher also supposed that the audio length, speed, and clarity have been well-suited with students' age and level. In terms of organization and layout of the book, the teacher perceived it very positively.

In addition to the Student Book, the teacher as the product practitioner also judged the Teacher's Guide covering the aspect of clarity of instruction, procedures, confidence, accuracy, and adequacy of answer keys, and providing alternative activities. The teacher commented that the Teacher's Guide has already provided clear and good instructions, provided well-presented procedures to use the book, given confidence to use the Teacher's Guide as his 'consultant' to practice various strategies and techniques in using the book and provided varied alternative for activities and accurate and adequate answer keys. Overall, the 
teacher's opinion on the product showed that the Teacher's Guide is very highly accepted.

In addition to the English teacher's opinion on the product after the limitedfield tryout, a questionnaire was also distributed to the students. Different from the teacher who was asked to give his opinion to both Students Book and Teacher's Guide, students were only asked to judge the Students Book. There were 34 students involved in the limited-field tryout.

For the aspect of contents, 69\% of the students really agreed and the remaining $31 \%$ agreed that the contents of the product are acceptable because the criteria in the questionnaire were consistently found in the product. For the aspect of skills, $100 \%$ of the students really agreed that the Students Book has wellthought-out to integrate all language skills in balance. For the aspects of tasks, $66 \%$ of the students really agreed and the remaining $34 \%$ agreed that the tasks in the product are varied and interestingly presented. For the aspect of audio, $38 \%$ of the students really agreed and the remaining $62 \%$ agreed that the audio length, speed, and clarity were believed to be appropriate to their level. The last aspect is graphics in which $62 \%$ of the students really agreed and the remaining $38 \%$ of the students agreed that the organization and layout of the product are very good and appealing.

Based on the findings during the limited-field tryout and the teacher's suggestions, some revisions were made. After that, the final product was assembled. The final product prototype consists of three main products: Student Book, Teacher's Guide, and Listening CD. The prototype of Student Book consists of two units. Each unit has a central theme and activities which employ all language skills and components. The tasks in the product in each unit consists of (1) Starter to introduce the topic and develop vocabulary by presenting pictures, charts, or diagram to trigger discussion, (2) It's Your Turn which is a controlled task in the form of conversation exercise is provided to introduce target grammar, functional, and conversational exercise in communicative context, (3) Language Focus tasks to develop learners' grammatical skills through guided and free activities, (4) Speak Up which is fluency exercise to give learners opportunity to develop their language skills in individual practice through pair work, group work or whole class activities, (5) Listening Challenges tasks to enrich learners' information through listening activity for gist, for details and for meaning inferences, (6) Word Power tasks to develop learners' vocabulary through a variety of tasks to provide them opportunity in using vocabulary in context, (7) Let's Write tasks to provide practical writing tasks, (8) Read On tasks to develop a variety of reading skills, (9) Let's Do a Project tasks to give students opportunity for their self-actualization of what they have studied in the unit taking the form of either written or oral tasks or individually or in groups, (10) Do You Know tasks to provide information related to content matters which can be used as extensive reading for learners outside the classroom for their own progression or enrichment, (11) Take the Challenge which present questions related to math and 
science contents, (12) ESL Tips to provide the users (students) some advices in doing English tests, (13) Review to give the students the chance to recycle the materials presented in the whole unit, and (14) Glossary which presents the target vocabularies with easy definitions to help students understand the terminology presented in English.

Apart from the students' book, the Teacher's Guide which contains the procedures of using the book, the alternative activities for students, listening transcript, and answer keys is also developed. The Listening CD contains the audio of all listening activities in the Student Book.

Table 1 Structure of the prototype of CLIL-oriented and task-based English materials

\begin{tabular}{llll}
\hline Concepts & Objective & $\begin{array}{l}\text { Tasks, Skills, Linguistic Features and } \\
\text { Materials }\end{array}$ & Pages
\end{tabular}

UNIT 1 LET ME TELL YOU ABOUT ...

\begin{tabular}{|c|c|c|c|}
\hline $\begin{array}{l}\text { Biography of } \\
\text { science-related } \\
\text { scientists with } \\
\text { their theories. }\end{array}$ & $\begin{array}{l}\text { The students are } \\
\text { able to: } \\
\text { 1. express } \\
\text { how to do } \\
\text { greetings, } \\
\text { introduction, } \\
\text { and leave- } \\
\text { takings; } \\
\text { 2. preview texts } \\
\text { about the } \\
\text { biography of } \\
\text { world } \\
\text { scientists; } \\
\text { 3. use simple } \\
\text { past to tell } \\
\text { past events; } \\
\text { 4. scan a text for } \\
\text { specific } \\
\text { information }\end{array}$ & $\begin{array}{l}\text { Starter (writing) } \\
\text { predicting pictures } \\
\text { It's your turn (controlled-speaking activity) } \\
\text { telling about favorite scientists guided with } \\
\text { flashcards (controlled activity) } \\
\text { Listening challenges (listening) } \\
\text { - listening to a dialogue about greetings, } \\
\text { introductions, and leave-takings (listening for } \\
\text { gist and for comprehension) } \\
\text { - listening to a monologue about the biography } \\
\text { of Carolus Linnaeus (information gap activity) } \\
\text { Read on (reading) } \\
\text { Reading the following texts: } \\
\text { - biography of John Dalton and his atomic } \\
\text { theory (note-taking activity) } \\
\text { - biography of Antoine Lavoisier and his theory } \\
\text { of Law of Conservation of Mass } \\
\text { (comprehension activity) } \\
\text { - biography of Helena Curtis and her Sign of } \\
\text { Life (matching activity) }\end{array}$ & $1-23$ \\
\hline
\end{tabular}


Let's write (writing)

- biography of Anders Celsius and his Celsius thermometer (rearranging activity)

- biography of Al Khwarizmi and his theory of Completion and Balancing (information transfer activity)

- biography of Antoine Lavoisier (completing story)

- writing answers

Word power (vocabularies)

Matching words with its meaning, jumbled

letters

Language focus ( rammar)

Simple past tense

Ways to say it (pronunciation)

Stress pattern

Let's do a project (free writing activity)

Writing a short biography of Indonesian scientist Cultural awareness

Handshaking around the world

Take the challenge

Questions related to the content topics discussed throughout the unit

ESL tips

Tips for reading comprehension and information transfer

\section{Let's review}

Vocabulary review and grammar review

Let's do reflection

Glossary

\begin{tabular}{|c|c|c|c|}
\hline \multicolumn{4}{|c|}{ UNIT 2 THAT'S A GREAT EXPERIENCE } \\
\hline \multirow[t]{4}{*}{$\begin{array}{l}\text { Personal } \\
\text { experiences }\end{array}$} & $\begin{array}{l}\text { The students are } \\
\text { able to: }\end{array}$ & $\begin{array}{l}\text { Starter (writing) } \\
\text { predicting pictures, predicting information }\end{array}$ & $24-45$ \\
\hline & $\begin{array}{l}\text { 1. express } \\
\text { happiness and } \\
\text { sympathy; }\end{array}$ & $\begin{array}{l}\text { It's your turn (controlled-speaking activity) } \\
\text { telling about personal experience (controlled } \\
\text { activity) }\end{array}$ & \\
\hline & $\begin{array}{l}\text { 2. preview } \\
\text { texts about the } \\
\text { past } \\
\text { experience; }\end{array}$ & $\begin{array}{l}\text { Listening challenges (listening) } \\
\text { - listening to a dialogue expressing happiness } \\
\text { and sympathy (listening for gist and } \\
\text { comprehension) }\end{array}$ & \\
\hline & $\begin{array}{l}3 . \quad \text { use past } \\
\text { continues to } \\
\text { tell past }\end{array}$ & $\begin{array}{l}\text { - listening to a monologue about the history of } \\
\text { biological classification (information gap } \\
\text { activity) }\end{array}$ & \\
\hline
\end{tabular}




$\begin{array}{ll}\text { events; } & \text { Speak up (free speaking activity) } \\ \text { 4. Scan a } & \text { expressing happiness and sympathy (roleplaying } \\ \text { text for } & \text { activity) } \\ \text { specific } & \text { Read on (reading) } \\ \text { information; } & \text { Reading the following texts: } \\ \text { 5. skim a } & \text { - A mother explains about his microcephaly son } \\ \text { text using } & \text { exposed by zika virus (comprehension activity) } \\ \text { section } & \text { - Ionic and covalent laboratory experiments } \\ \text { headings } & \text { (information transfer activity) } \\ & \text { - Herpes simplex (comprehension activity) } \\ & \text { Let's write (writing) } \\ & \text { - Alarming dying vultures in India caused by an } \\ & \text { unknown virus (note-taking activity) } \\ & \text { • writing answers } \\ & \text { Word power (vocabularies) } \\ & \text { Word class } \\ & \text { Language focus (grammar) } \\ & \text { Past continuous } \\ & \text { Ways to say it (pronunciation) } \\ & \text { Pronunciation of -ed/-d past tense } \\ & \text { Let's do a project (free speaking activity) } \\ & \text { Doing observation and report it orally } \\ \text { Cultural awareness } \\ \text { Smiles in different cultures } \\ \text { Take the challenge } \\ \text { Questions related to the content topics discussed } \\ \text { throughout the unit } \\ \text { ESL tips } \\ \text { Tips for note-taking activity } \\ \text { Let's review } \\ \text { Vocabulary review and grammar review } \\ \text { Let's do reflection } \\ \text { Glossary } \\ & \end{array}$

\section{Discussion}

After the underlying concepts and the principles of the product development in the present study was reviewed and reformulated with the purpose of relevance and facilitating the writing of the product drafts, the basic concepts, and principles as formulated, can be used as the reference in developing the CLIL-oriented and task-based EFL materials in the present study. However, some challenges were encountered especially during the development of tasks. The integration of content and language requires careful text selection especially because it was likely difficult to get appropriate texts relevant to the students' needs in their content (subject-matter) class and at the same time suitable to be used in EFL 
classroom. The employment of FGD with content teachers and EFL teachers is highly recommended to meet the needs both content and EFL teachers.

Another challenge was despite the fact that students commented positively toward the product resulted in the present study, for many CLIL researchers who work in EFL settings, including the present researcher, it is undeniable that the topic selection sometimes contradictory between what the teachers want to teach and what the students want to learn. As CLIL teachers are language teachers in the context of the present study, it was found that they think that their content knowledge about specific topics might be insufficient which also things for concern in the materials developed in the present study of which topics dealt with the content area (math and sciences). Therefore Ikeda (2013) and Sasajima (2013) suggest taking this issue to be considered in relation to the school development programs. Schools should make a revolutionary breakthrough to bridge between the importance of language in communicating content in vehicular language to prepare students for their higher education and the importance of non-language content in foreign language learning in order that EFL teaching meets the needs and expectation of the learners on using language appropriate to their interests. There was also concern about the difficulty in providing balance toward skills throughout the product. Despite the fact that the product in the present study employed integrated skills and components, the immense number of reading activities is vividly seen. This was not without reason. Reading activities are helpful to provide students with rich input especially related to subject-specific vocabularies. However, EFL learners are often marginalized as readers where the activities of reading for pleasure or reading for meaning are often taken for granted. Mostly, as Oughton (2007) avows, EFL teachers present reading texts merely to analyze new vocabulary items or linguistic structure. Even if EFL teachers have the ability to present reading activities well, students still get difficulty comprehending the text especially if the text is long and not helping the students to understand the text. This somewhat often happens when students deal with reading passages in content area. Most often, the contents such as science and social contents that are integrated into EFL learning textbooks/ course books contain very long text. This leads to students' boredom and demotivates them to read. Therefore in developing materials that integrate content and language, it is highly suggested that inputs be varied. Multimodal inputs, which have been considered in materials development in the present study, such as texts, charts, visuals, bulleted-points, diagrams, etc. are highly recommended to make students get easier to understand the content.

The idea of incorporating content topics in EFL materials resonates what Yoshihara (2011) found that EFL learners preferred EFL learning to include topics related to their major. Through the learning of language using topics related to their major and interest, students are provided with the opportunity to build their confidence, communication skills, and self-expression. 


\section{CONCLUSION}

This study resulted in the prototype of three main products: a coursebook entitled [prototype of] Interweave: an English Coursebook for the Tenths Grade of Senior High School, a teacher's guide, and a listening CD. The coursebook contains topics in content lessons, mainly Maths, Biology, Physics, and Chemistry, presented in integrated skills and components. The prototype consists of two units developed based on recount text type, a text aims to tell past events. Each unit bears different themes. Unit 1 was developed based on biography theme while unit 2 was developed in past experience theme.
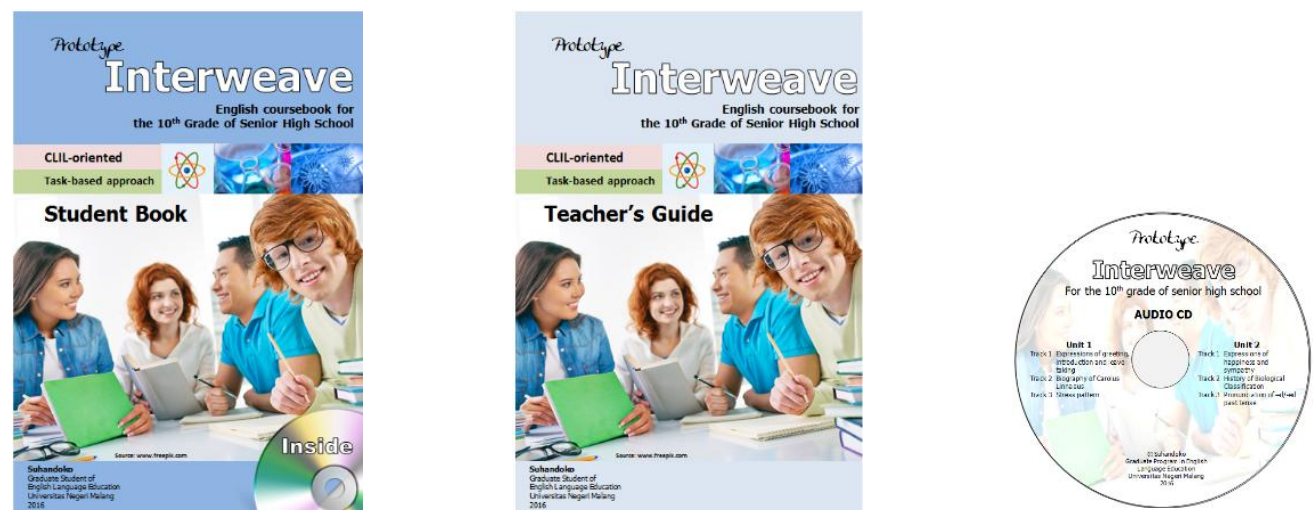

\section{Figure 2 Student Book, Teacher's Guide, and Listening Audio CD}

However, nothing is perfect under the sky. Despite the fact that the product in the present study was developed with ample efforts, the researcher admits that some issues related to product development in the present study need to be addressed. The first issue is related to the coverage of the coursebook itself. The product in the present study was developed in the form of prototype which may make dissemination in wider setting cannot be done in immediate time. Further development is still required and, consequently, more time, financial and human resources are mandatory. The second issue is related to the topic coverage within the coursebook. The large number of content-area topics put the researcher out of action to cover them all. Instead, the topics covered, based on the discussion with content area teachers, are the most considered important and basic to help students in their content area lessons in which English is used as the medium of instruction. The third issue is related to the involvement of small subjects in empirical validation. In order to verify the validity and acceptability of the product for users, experts often recommend using wider subject in the empirical validation phase to get more inputs and degree of

Based on the limitations outlined above, the researcher also offers several suggestions for future works related to the present study. Firstly, EFL teacherresearchers who want to embark on R\&D research in quality CLIL materials need to be aware of the extent the degree of acceptability of the product; therefore, involving more subjects especially in empirical validation is significant. This is to 
ensure that the product will bring more impacts to the development of English language teaching.

The second is related to the question whether the product developed in the present study contributes to learners' English proficiency. For this purpose, suggestions for testing the product followed by examining students' proficiency after the product implementation is recommended and by so doing the effectiveness of the product can only be figured out.

After being assured that the product is effective in the teaching of English, a further study employing classroom action research aims at improving learners' English proficiency using the product in the present study or such materials developed following the conceptual designed proposed in this study is worth to conduct.

The most important aspects of successful CLIL-oriented materials development as Wegner (2012:34) mentions, which also have been a story of itself in this thesis about these needs, are mutual recognition, joint negotiation joint experimentation also food for thought for future CLIL-related research.

\section{REFERENCES}

Anderson, L. W, Krathwohl, D.R., Bloom. B. (2001). A Taxonomy for Learning, Teaching and Assessing: A Revision of Bloom's Taxonomy of Educational Objectives. New York: Longman

Banegas. D. L. (2013). Three Frameworks for Developing CLIL Materials. University of Warwick and Argentina

Bravos, K. (2010). Readability tests and formulas. Retrieved from http://www.ideosity.com/ 2010/01/14/readability-tests-and-formulas Brown. H. D. (2007). Teaching by Principles: An Interactive Approach to Language Pedagogy ( $3^{r d}$ ed.). NY: Pearson Education Inc.

Coyle, D., Hood, P., \& Marsh, D. (2010). CLIL: Content and Language Integrated Learning. Cambridge: Cambridge University Press.

Cummins, J. (2000). BICS and CALP: clarifying the distinction. ERIC retrieved http://files.eric.ed.gov/fulltext/ED438551.pdf on December 15, 2015.

Ellis, R. 2003. Task-Based Language Learning and Teaching. Oxford, U.K.: Oxford University Press.

Ellis, R. 2009. Task-based language teaching sorting out the misunderstandings. International Journal of Applied Linguistics, 19(3), 221-246.

Gall, M.D., Gall, J.P., \& Borg, W.R. (2003). Educational Research: An Introduction $\left(7^{\text {th }}\right.$ ed.). New York: Longman Inc. 
García. S. 2013. Three frameworks for developing CLIL materials in infant and primary education. Encuentro 22, 2013, ISSN 1989-0796, pp. 49-53

Gray, J. (2010). The branding of English and the culture of the new capitalism: Representations of the world of work in English language textbooks. Applied Linguistics, 31(5), 714-733.

Harmer, J. (2007). The Practice of English Language Teaching ( $4^{\text {th }}$ ed.). England: Pearson Education Limited.

Ikeda, M. (2013). Does CLIL work for Japanese secondary school students?: Potential for the 'weak' version of CLIL. International CLIL Research Journal, 2(1), 31-43. Retrieved from http://www.icrj.eu/21/article3.html

Lee, W.W. \& Owens, D.L. (2004). Multimedia-Based Instructional Design $\left(^{\text {nd }}\right.$ ed.). San Fransisco: John Wiley \& Sons Inc.

Mehisto, P., Marsh, D., \& Frigols, M. (2008). Uncovering CLIL: Content and language integrated learning in bilingual and multilingual education. Oxford: Macmillan.

Moore, P. \& Lorenzo, F. (2015).Task-based learning and content and language integrated learning materials design: process and product, The Language Learning Journal, 43:3, 334-357, DOI: 10.1080/09571736.2015.1053282

Nunan, D. (2004). Task-Based Language Teaching. Cambridge: Cambridge University Press.

Oughton, H. (2007). Constructing the 'ideal learner': a critical discourse analysis of the adult numeracy core curriculum." Research in Post-Compulsory Education 12 (2): 259-275. http://dx.doi.org/10.1080/13596740701387536 Sasajima, S. (2013). How CLIL can impact on EFL teachers' mindsets about teaching and learning: An exploratory study on teacher cognition. International CLIL Research Journal, 2(1), 55-66. Retrieved from http://www.icrj.eu/21/article5.html

Schlegel, M.J. (1995). A handbook of instructional and training program. Educational Resource Information Center (ERIC) http://www.eric.ed.gov/\%3Fid\%3DED383381 retrieved November 13, 2015

Sherman, J. E. (2010). Multiple levels of cultural bias in TESOL course books. RELC Journal, 41(3), 267-281.

Tomlinson, B. (2012). Materials Development for Language Learning and Teaching. Cambridge: Cambridge University Press.

Van den Branden, K. (2006). Task-Based Language Education: From Theory to Practice. Cambridge: Cambridge University Press. 
Willis, J. (2006). A Framework for Task-based Learning. London: Longman.

Yoshihara, R. (2011). Learning and teaching gender and sexuality issues in the EFL classroom: Where students and teachers stand. Journal and Proceedings of the Gender Awareness in Language Education, 4, 5-21. 